\title{
A diuretikum-refrakter szívelégtelen betegek körében alkalmazott peritonealis dialízissel szerzett tapasztalataink
}

\author{
P. Szabó Réka1, Pethő Ákos², Fedor Roland³, Kertész Attila4, \\ Bódi Annamária ${ }^{4}$, Szegedi Andrea ${ }^{4}$, Balla József ${ }^{5}$
}

\author{
${ }^{1}$ DE ÁOK, Sebészeti Intézet, Debrecen \\ ${ }^{2}$ Semmelweis Egyetem I. sz. Belgyógyászati Klinika, Budapest \\ ${ }^{3} \mathrm{DE}$ ÁOK, Sebészeti Intézet, Debrecen \\ ${ }^{4} \mathrm{DE}$ ÁOK, Kardiológiai Intézet, Debrecen \\ ${ }^{5} \mathrm{DE}$ ÁOK, Belgyógyászati Intézet, FMC-Debrecen, Extrakorporális Szervpótló Centrum, Debrecen
}

Levelezési cím: Dr. P. Szabó Réka, e-mail: rpszabo@belklinika.com

\begin{abstract}
Bevezetés: Klinikánkon négy éve alkalmazunk perkután PD katéter-beültetést és peritoenális dialízis kezelést a súlyosan csökkent bal kamra szisztolés funkcióval bíró, diuretikum-refrakter szívelégtelen betegek körében. Célul tüztük ki, hogy leírjuk centrumunk ebben a betegcsoportban szerzett tapasztalatát.

Betegek, módszerek: 2014 áprilisától követtük betegeinket a követési idő vége 2018. január volt.

Eredmények: Hat páciensünk közül háromnál nem iszkémiás etiológiájú csökkent ejekciós frakciójú szívelégtelenség, háromnál iszkémiás etiológiájú csökkent ejekciós frakciójú szívelégtelenség talaján alakult végstádiumú szívelégtelenség. Charlson komorbiditási index alapján 6-10 pont közötti értékeik voltak. A PD katéterbeültetés perkután technikával történt, az ultrafiltrációt azonnal el tudtuk kezdeni. Két betegünk sikeres szívtranszplantáción esett át. Három betegünk hunyt el, halálok nem PD asszociált szövődmény volt, 1 traumás, 1 egyéb infekció, 1 szívelégtelenség.

Következtetések: A diuretikum-refrakter szívelégtelenség esetén a peritonealis dialízissel javulhat a jobb és bal kamra funkciója is. Centrumunkban kezeltünk elsőként PD-vel - áthidaló terápiaként -, hazánkban szívelégtelen beteget a szívtranszplantációig.
\end{abstract}

Kulcsszavak: szívelégtelenség, peritonealis dialízis, szívtranszplantáció, transzplantáció, veseelégtelenség

\section{Peritoneal ultrafiltration for refractory heart failure: single-center experience}

Introduction: In our centre we have been treated patients with therapy refracter congestive heart failure. The aim of this study was to describe a single-center experience in the treatment of refractory HF patients with peritoneal dialysis (PD).

Methods: Our study included in a single PD Unit, showing symptoms and signs of severe refractory congestive HF to optimal pharmacological therapy (NYHA class IV). We followed them till January 2018.

Results: Patients were followed for 10 months; population mean age was 58 years and Charlson's comorbidity index was 6-10. We could start peritoneal dialysis immediately after catheter implantation. Three patients died but not according to PD associated infection: 1 traumatic, 1 due to HF, another patient due to infection.

Conclusion: PD, applied to refractory HF can improve functional class. In Hungary we used peritoneal dialysis first time as a bridge therapy to heart transplantation in diuretic refracter heart failure.

Keywords: heart failure, peritoneal dialysis, heart transplantation, kidney failure 


\section{Bevezetés}

A szívelégtelenség (SZE) prevalenciája 6-10\% 65 év feletti korosztályban, a 70-80 év között pedig 10-20\%. Az USA-ban közel 5 millió, Európában 15 millió ember szenved SZE-ben. A 65 év felettiek kórházi felvételének leggyakoribb oka a SZE. A diagnózis felállítását követő 5 évben a betegek közel 50\%-a meghal. Ez megfelel a közepes súlyosságú colon karcinóma halálozásának. A gyógyszeres kezelés magában foglalja az ACE-gátlók, béta-blokkolók, aldoszteron-antagonisták, angiotenzinreceptor-blokkolók, hydralazin+izoszorbid-dinitrát (H-ISDN), digoxin, diuretikumok, ARNI, ivabradin alkalmazását. Az eszközös kezelés: a CRT-P (kardiális reszinkronizációs terápia-pacemaker), CRT-D (kardiális reszinkronizációs terápia-defibrillátor), LVAD (left ventricular assist device), ICD (implantálható kardioverter defibrillátor). Egyes esetekben pedig a peritonealis dialízis, hemodialízis, ultrafiltráció szintén megpróbálhatóak híd terápiaként a szívtranszplantációig (1-6). A peritonealis dialízis során a folyadék- és salakanyag eltávolítása intrakorporálisan történik, a beteg magának végzi az oldatcseréket - egy oldatcsere $\mathrm{kb}$. 20-30 percet vesz igénybe -, amely során a PD-katéteren keresztül engedi be a standarden 2 liter volumenú oldatot (a beengedett volumen módosulhat 500-2500 ml között), majd azt megfelelő benntartási idő után leengedi (4). A peritonealis dialízis során az oldatcsere száma függ a beteg hashártya-transzporter típusától (lassú, gyors, átlagosan gyors transzporter), amelyet a PET-teszttel (peritonealis ekvilibrációs teszt) határozunk meg. Amennyiben gyors transzporter a betegünk automatakezelést javaslunk, ilyenkor az oldatcserét készülék végzi kisebb volumenekkel (APD, cycler).

A kardiorenális szindrómák a szív és a vesék együttes megbetegedései. Ezekben az esetekben az egyik szervnek az akut vagy krónikus morfológiai és/vagy funkcionális károsodása a másik szervben másodlagosan okoz akut vagy krónikus morfológiai és/vagy müködési zavart. A kardiorenális szindrómákat öt típusba soroljuk.

- Az 1-es típus: akut kardiorenális szindróma, ez a kardiális funkció akut csökkenése, amely a vesék rapidan kialakuló morfológiai és/vagy funkcionális károsodásához vezet.

- A 2-es típus, amikor krónikus szívbetegségekben az idült kardiális funkciózavar hosszabb idő alatt vezet a vesék morfológiai és/vagy funkcionális károsodásához.

-A 3-as típus esetén ez fordítva történik, mert a vesefunkció akut csökkenése (akut vesekárosodás) vezet a szív morfológiai és/vagy funkcionális károsodásához.

- A 4-es típusban a különböző eredetü krónikus vesebetegségek, vezetnek hosszabb idő alatt a szív morfológiai és/vagy funkcionális károsodásához.

- Az 5-ös típus esetén különböző akut vagy krónikus
1. TÁBLÁZAT. Tanulmányok, esetriportok, amelyekben peritonealis dialízist alkalmaztak szívelégtelenségben

\begin{tabular}{|l|l|r|}
\hline Hivatkozás & Tanulmány típusa & Betegszám \\
\hline Schneierson & Esetriport & 1 \\
\hline Mailloux & Esetriport & 15 \\
\hline Konig & Prospektív, nem randomizált & 13 \\
\hline Ryckelynck & Prospektív, nem randomizált & 16 \\
\hline Bilora & Prospektív, nem randomizált & 16 \\
\hline Aggrawal & Retrospektív & 20 \\
\hline Oritz & Esetriport & 3 \\
\hline Gotlib & Prospektív, nem randomizált & 20 \\
\hline Salvatori & Esetriport & 1 \\
\hline Phadke & Esetriport & 1 \\
\hline Prochnicka & Esetriport & 1 \\
\hline Sanchez & Prospektív, nem randomizált & 17 \\
\hline Soitrakopoulos & Prospektív, nem randomizált & 19 \\
\hline Prochnicka & Esetriport & 1 \\
\hline Bertoli & Retrospektív & 48 \\
\hline
\end{tabular}

szisztémás betegségek vezetnek egy időben a szív és a vesék esetén is észlelt morfológiai és/vagy funkcionális károsodásokhoz (7).

A kardiorenális szindróma patomechanizmusa összetett. Számos urémiás toxinról mutatták ki, hogy a cardiomyocyták gap junctionjaiban irreverzibilis változást hoznak létre, ami a vesekárosodott betegek szívbetegségét rontja a klasszikus rizikófaktorok mellett (8). A szívelégtelen, kardiális cachexiás betegek vastagbél mucosaja magasabb kolonizációt mutat, amelyek emelkedett gyulladásos citokinek termelődését okozzák. A peritoenalis dialízissel ezen citokinek clearance-e csökkenthető (9). A peritonealis dialízis (PD), amelyet Schneierson alkalmazott elsőként 1949-ben, bizonyítottan jól és biztonsággal alkalmazható alternatív módszer veseelégtelen betegek tartós szupportív kezelésében. Az 1. táblázat összegzi azokat a tanulmányokat, amelyekben peritonealis dialízist alkalmaztak szívelégtelenségben (10-16). A PD-kezelés előnyösebb a szívelégtelen betegek számára, mert a folyamatos, intrakorporális folyadék eltávolítása kíméletesebb az extrakorporális kezelésnél, nem jár hipotóniával, a beteg otthonában is végezheti, nem szükséges hozzá szakszemélyzet, a beteg maga végzi a kezelést. A szívelégtelenség bázisterápiáját képező aldoszteron-antagonisták és RAS-gátlók a káliumretenció miatt korlátozottan alkalmazhatóak a vesefunkció romlásakor. A fokozott szimpatikus tónus, RAS-aktiváció következtében kevesebb nátrium jut a disztális tubulusokba, kombinált diuretikus terápia ellenére fokozódó és ismétlődő dekompenzáció jelentkezhetnek. Ilyen esetekben a diuretikum kombinációk alkalmazása javasolt (furosemid: $250-500 \mathrm{mg} / \mathrm{nap}$, inadapamid: 1,5 mg, aldoszteron-antagonisták: 25-50-100 mg).

Mikor válasszuk a PD-t szívelégtelen betegünknél 


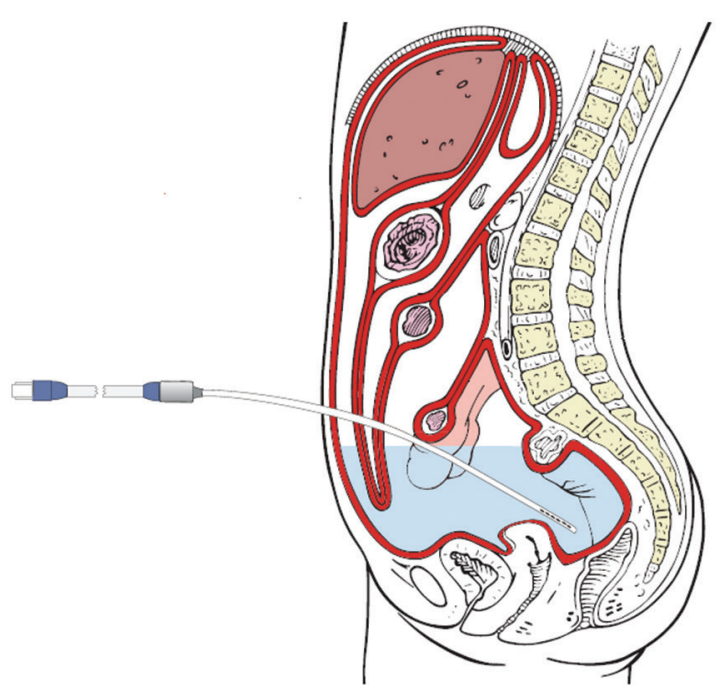

1. ÁBRA. A PD katéter lokalizációja. https://www.nkfs.org/ treatment/peritoneal-dialysis/about-peritoneal-dialysis/

(1. ábra)? Terápiarezisztens vizenyők, ascites, vesefunkciós értékek emelkedése, GFR csökkenése, hipotónia, kardiális cachexia, leromlott állapotú beteg esetén. Centrumunkban kardiológus referálja a beteget PD-ben jártas nefrológusnak, közös döntés születik a kezelési mód bevezetéséről. Nem javasolt perkután technika korábbi mütétek, összenövések lehetősége miatt, illetve ha a beteg elutasítja a kezelést. Amennyiben perifériás érbetegség, érmütét szerepel a kórelőzményben, az intraabdominális nyomás emelésével a dysbasiás panaszok progrediálhatnak. Ha a betegnél nem diuretikum-refrakter ödéma esete áll fenn, a konzílium során ellenőrizzük a folyadék-megszorítás kérdését, a diuretikum dózist. Amennyiben obstipáló betegünk van, javasolt a széklet rendezése, mert ellenkező esetben megnöveljük a PD-asszoiciált peritonitis lehetőségét, a Gram-negatív baktérium-transzpozíció miatt. Szintén nem javasoljuk diabéteszes enteropathia, neuropathia, hasmenés esetén sem ezt a kezelési módot. A beültetés előtt javasoljunk vizeletvizsgálatot, orr-garatváladék tenyészést, hasi UH-t, a hemosztázis rendezését, lehetőleg a hasi régióba szubkután injekció beadása kerülendő (2. ábra).

\section{Betegek, módszerek}

Klinikánkon négy éve alkalmazunk PD-kezelést súlyosan csökkent bal kamra szisztolés funkcióval bíró krónikus szívelégtelen betegek körében. 2014 áprilisától követtük betegeinket, 2018. januárig. Hat betegünk eredményét ismertetjük, részletezve a hospitalizációs napok változását a PD-kezelés indítását követően, a testsúlyváltozást, a bal- és jobbkamra-funkcióban bekövetkező javulást. A dialízis hatékonyságát a PET (peritoneális ekvilibrációs tesz) teszttel és a heti clearance-szel álla- pítottuk meg. BCM (body composition monitor) méréssel követjük a betegeink hidrációs állapotát, az oldatcserék számát, az alkalmazott oldatok töménységét a súlytöbblet mértékéhez és a hashártya-transzport karakterikához (D/P - lassú, átlagos, gyors) igazítjuk, a diuretikumok dóziást titráljuk a vérnyomás, az ultrafiltráció, a reziduális diurézis, a szérum elektrolit ( $\mathrm{Na}, \mathrm{K}, \mathrm{Ca})$ szinteknek megfelelően. A beteg kezelő lapon rögzíti az oldatcserénél befolyatott majd kifolyt oldat mennyiségét, naponta rögzíti a testsúlyát, a vizeletmennyiséget, vérnyomásértékeket. $A$ PD-oldatok közül többnyire a 2 literes $1,5 \%$-os vagy a 2,3\%-os glükóztartalmút alkalmazunk, icodextrint nem használtunk.

\section{Eredmények}

Diuretikum-refrakter vizenyők miatt hat betegnél indítottunk peritoenális dialízist, 2014. április 15. - 2018. január 10-e között követtük őket. A betegek NYHA IIIIV. stádiumú szívelégtelen betegek voltak, közülük egy volt diabéteszes. Három iszkémiás etiológiájú csökkent ejekciós frakciójú szívelégtelenség, három nem iszkémiás etiológiájú csökkent ejekciós frakciójú szívelégtelen beteg volt. 1 nő, 5 férfi beteg volt, átlagéletkoruk: 58 év volt. A hat beteg közül négy szívtranszplantációra alkalmatlan volt komorbiditása miatt. Átlagosan 10,8 hónapot voltak a PD-programban. Egy betegnél a perkután $\mathrm{PD}$-beültetés korai időszakában nem tudtunk effektív ultrafiltrációt végezni, belőle 1 hónap után a katétert sebészi úton távolítottuk el. Egy betegünknél 10 hónap után katéter malfunckió lépett föl, szintén a katéter eltávolítására kényszerültünk, ő a vizsgált időszakban javult kamrafunkcióval, vesepótló kezelés nélkül jól van. Infektív szövődményt 1 betegünknél észleltünk, katéter exsite site infekciót, és egy alkalommal PD peritonitist. Az elhunyt betegeink nem PD-asszociálta szövődmény következtében hunytak el. Charlson komorbiditási indexük átlagosan 7,8 (tartomány 6-10) volt. Eritropoietint nem kaptak, vérképük a célérték 100-120 g/l feletti volt. PD rezsim: glükózalapú oldat volt 1,5-2,3\%-os, izodextrint nem használtunk. Vesefunkciójuk: GFR: 20-10 közötti volt. Reziduális diurézisük megtartott volt: 1,5-2 liter közötti. APD-s betegünk nem volt. Átlagos testsúlycsökkenés 6,4 kg-nak adódott az effektív PD-kezelés elkezdését követően az első két hétben, és ezt az értéket tartották is 4 héttel, 8 héttel e kezelés indítását követően is. A szívelégtelenség miatti hospitalizációs napok száma csökkent (2. táblázat). Az alkalmazott diuretikumok köre kibővíthető volt, szekvenciális blokádot alkalmazva (indapamid, spironolacton, furosemid, chlortalidon, etakrinsav) a reziduális diurézis növelhető volt. Az elhunyt betegeinket átlagosan 16 hónapig kezeltük. A három betegünk közül ketten sikeres szívtraszplantáción estek át, egyiküknél a posztoperatív szakban is alkalmazták a PD-t. Egy betegünk a követési idő végén, 36 hónappal, PD nélkül 


\begin{tabular}{|c|c|c|c|c|c|c|}
\hline $\begin{array}{l}\text { Életkor/ } \\
\text { nem }\end{array}$ & $\begin{array}{l}\text { Alap- } \\
\text { betegség }\end{array}$ & $\begin{array}{l}\text { PD elötti évben } \\
\text { hospitalizáció } \\
\text { (napok), azt } \\
\text { követő évben }\end{array}$ & $\begin{array}{l}\text { Testsúly- } \\
\text { csökkenés a } \\
\text { PD indítását } \\
\text { követően (kg) } \\
\text { két héttel }\end{array}$ & $\begin{array}{l}\text { PD-ben } \\
\text { eltöltött } \\
\text { hónapok, } \\
\text { peritonitis }\end{array}$ & $\begin{array}{l}\text { EF PD elött EF PD } \\
\text { után, NYHA stádium, } \\
\text { balkamra- és jobb- } \\
\text { kamra-funkció válto- } \\
\text { zása PD-t követően }\end{array}$ & $\begin{array}{l}\text { Kimenetel } \\
\text { (2018. január) }\end{array}$ \\
\hline 56 é nő & DCM & $35-0$ & 5 & $17 / 0$ & $15 \%-15 \%$ IV-IV & $\begin{array}{l}\text { Exit: } \\
\text { Erysipelas, szepszis }\end{array}$ \\
\hline 67 é férfi & $\mathrm{DCM}$ & $168-5$ & 6 & $17 / 0$ & $20 \%-34 \%$ IV-III & $\begin{array}{l}\text { Exit, subdurális } \\
\text { haematoma }\end{array}$ \\
\hline 61 év férfi & ISZB & $30-3$ & 5 & $16 / 0$ & $18 \%-27 \%$ IV-III & Exit SZE \\
\hline 42 férfi & DCM & - & - & $1 / 0$ & - & Szív tx, él \\
\hline 56 férfi & ISZB & - & 11 & $4 / 0$ & $\begin{array}{l}\text { 27-30\% IV-II Echo pa- } \\
\text { raméterek: TAPSE (mm) } \\
\text { 7-8-ra nőtt, SV: 50-66 } \\
\text { ml-re nőtt } \\
\text { Swan Ganz: PVR: 291-120 } \\
\text { (DS/cm) }\end{array}$ & Szív tx, él \\
\hline 71 férfi & ISZB & $210-5$ & 5 & $10 / 1$ & $20 \%-40 \%$ III-II & Stabil, él EF: $40 \%$ \\
\hline
\end{tabular}

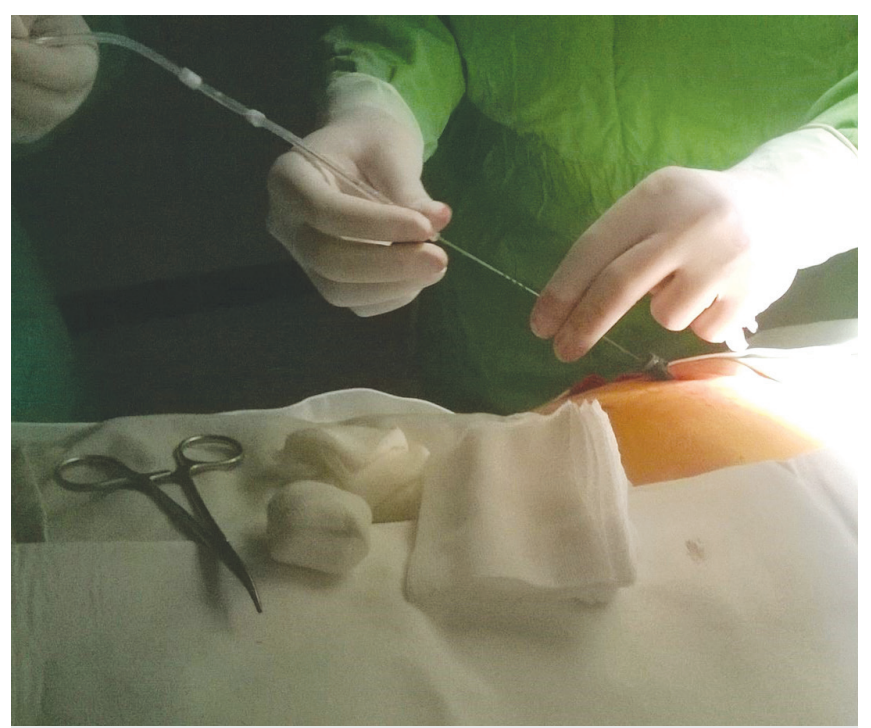

2. ÁBRA. Perkután PD katéterbeültetés (dr. Pethő anyagából)

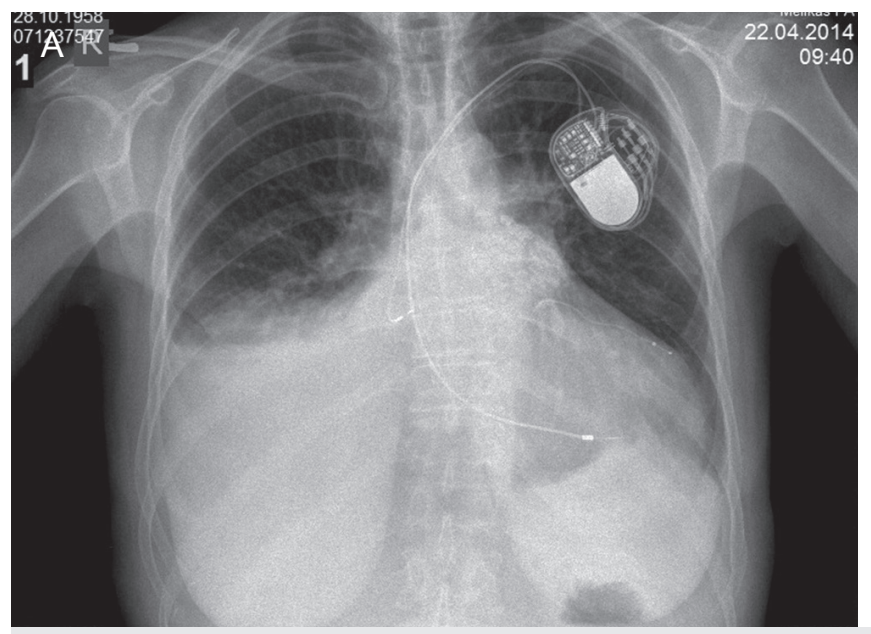

javult ejekciós frakcióval él. A 2. táblázat fogalja össze az eredményeket. A 3. ábrán látható a harmadik víztér, a mellkasi folyadékgyülem csökkenése a PD indítást követően két héttel (17).

\section{Megbeszélés}

A peritonealis dialízis alternatív kezelési mód lehet a terápia-refrakter szívelégtelen betegeknél. A kezeléssel csökkenthető az intraabdominális nyomás, az ultrafiltrációval javítható a hemodinamika (Frank-Starling-görbe balra tolható). A proinflammatorikus citokinek peritonealis clearance-ével javítható az EF. Az irodalmi adatokkal korrelálnak eredményeink: betegeink hospitalizációja csökkent, életminőségük és a diuretikumra adott válaszuk javult a PD alkalmazásával. Centrumunk gyakorlata alapján a gondozó kardiológus referálja a beteget a nefrológusnak NYHA stádiumtól függően

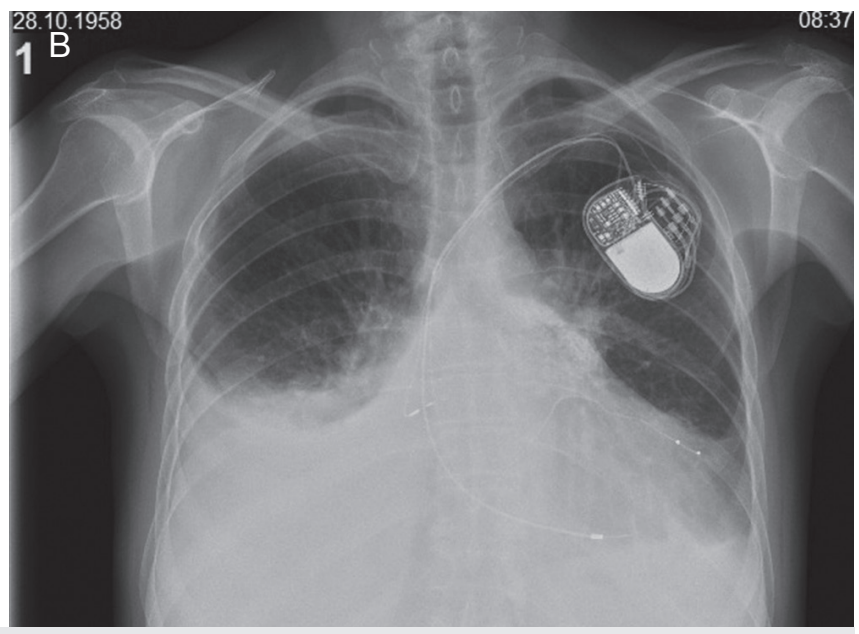

3. ÁBRA. A mellkasi folyadékgyülem csökkenése, a harmadik víztér. A: PD indítás előtt B: peritoneális dialízist követően 2 hét múlva 
(III-IV.), terápia-refrakter esetekben (Furosemid dózis $500 \mathrm{mg} / \mathrm{nap}$, napi folyadékbevitel nem haladja meg az ürített vizeletmennyiség +600 ml-t, kombinált diretikum terápia mellett). A beteg PD-re való alkalmasságát: PD-ben gyakorlott nefrológus mondja ki - figyelembe véve az általános PD-indikációk, és a relatív kontraindikációk szabta határokat (lásd a beteg kórelőzménye!). A PD-vel a szívelégtelen betegek életminősége javítható, csökken a hospitalizációk száma, javulhat a bal- és jobbkamra-funkció. A PD hídterápia lehet a szívtranszplantációig, amit elsőként alkalmaztuk centrumunkban, hazánkban. Az irodalmi adatokkal egyezően betegeinknél is (15) csökkent a dekompenzáció miatti kórházi felvételek száma, és javult betegünk életminősége. A peritoneális dialízissel a szívelégtelenség terápiás palettája kiegészíthető válogatott esetekben. A jól megválasztott esetekben a PD-asszociált szövődmények lehetősége minimálisra csökkenthető, biztonságossá téve ezen vulnerabilis betegcsoport kezelését.

\section{Irodalom}

1. Ellison $\mathrm{DH}$. The physiologic basis of diuretic synergism: its role in treating diuretic resistance. Ann Intern Med 1991; 114: 886-894. DOI: https://doi.org/10.7326/0003-4819-114-10-886

2. Sheppard R, Panyon J, Pohwani AL. Intermittent outpatient ultrafiltration for the treatment of severe refractory congestive heart failure. J Card Fail 2004; 10: 380-383. DOI: https://doi.org/10.1016/j. cardfail.2003.12.003

3. Krishnan A, Oreopoulos DG. Peritoneal dialysis in congestive heart failure. Adv Perit Dial 2007; 23: 82-89. DOI: https://doi. org/10.24170/4-3-2086

4. Broekman KE, Sinkeler SJ, Waanders F, et al. Volume control in treatment-resistant congestive heart failure: role for peritoneal dialysis. Heart Fail Rev 2014; 19(6): 709-16. DOI: https://doi.org/10.1007/ s10741-014-9421-3

5. Koch M, Haastert B, Kohnle M, Rump LC, et al. Peritoneal dialysis relieves clinical symptoms and is well tolerated in patients with refractory heart failure and chronic kidney disease. European Jour- nal of Heart Failure 2012; 4(5): 530-9. DOI: https://doi.org/10.1093/ eurjhf/hfs035

6. Karlien François, Joanne M Bargman., Evaluating the benefits of home-based peritoneal dialysis. International Journal of Nephrology and Renovascular Disease 2014; 7: 447-455. DOI: https://doi. org/10.2147/IJNRD.S50527

7. Ronco C, et al. Cardiorenal syndromes. European Heart Journal 2010; 31: 703-711. DOI: https://doi.org/10.1016/j.jacc.2008.07.051

8. Verbrugge $F H$, Dupont $M$, Steels $P$, et al. Abdominal contributions to cardiorenal dysfunction in congestive heart failure. J Am Coll Cardiol 2013 Aug 6; 62(6): 485-95. DOI: https://doi.org/10.1016/j. jacc. 2013.04.070

9. Anja Sandek, et al. Altered intestinal function in patients with chronic heart failure. J Am Coll Cardiol 2007. DOI: https://doi.org/10.1016/j.jacc. 2007.07.016

10. Schneierson SJ. Continuous peritoneal irrigation in the treatment of intractable edema of cardiac origin. Am J Med Sci 1949; 218: $76-9$

11. Mailloux LU, Swartz CD, Onesti G, et al. Peritoneal dialysis for refractory congestive heart failure. JAMA 1967; 199: 873-8. DOI: https://doi.org/10.1001/jama.1967.03120120061007

12. König $P$, Geissler $D$, Lechleitner $P$, et al. Improved management of congestive heart failure. Use of continuous ambulatory peritoneal dialysis. Arch Intern Med 1987; 147: 1031-4. DOI: https://doi. org/10.1001/archinte.1987.00370060027005

13. Ryckelynck JP, Lobbedez T, Valette B, et al. Peritoneal ultrafiltration and refractory congestive heart failure. Adv Perit Dial 1997; 13: $93-7$.

14. Bilora F, Petrobelli F, Boccioletti V, Pomerri F. Treatment of heart failure and ascites with ultrafiltration in patients with intractable alcoholic cardiomyopathy. Panminerva Med 2002; 44: 23-25.

15. Aggarwal HK, Sumit, Nand N, et al. Evaluation of role of acute intermittent peritoneal dialysis in resistant congestive heart failure. J Assoc Physicians India 2002; 50: 1115-1119.

16. Renhua LU, Muciño-Bermejo Mj, Claudino Riberio L, et al. Peritoneal Dialysis in Patients with Refractory Congestive Heart Failure: A Systematic Review. Cardiorenal Med 2015; 5: 145-156. DOI: https://doi.org/10.1159/000380915

17. Pethő ÁG, P. Szabó R, Szűcs A, et al. Percutan peritonealis dialízis katéterének behelyezése képerősítő mellett Seldinger-technikával. Lege Artis Medicinae 2014; 24(12): 601-604

\section{Tisztelt Olvasónk!}

Kiadónk, megfelelve a 2018. május 25-én életbe lépett, személyes adatok védelméről szóló EU rendelet (GDPR) szabályainak és elöírásainak, módosította Általános Adatkezelési Nyilatkozatát, mely elérhetö a www.promenade.hu/gdpr weboldalon.

Amennyiben már regisztrált a www.olo.hu portálrendszerben és/vagy a www.congressreport.eu oldalon és még nem fogadta el az arra vonatkozó adatkezelési szabályzat módosításával kapcsolatos, hírlevelünkben megküldött információkat, azt megteheti a hírlevélben található IGEN gombra kattintva.

Köszönjük, hogy Ön is olvasóink táborát erősíti és ezáltal hozzásegithetjük a legfrissebb szakmai információkhoz.

Promenade Kiadói Csoport 